\title{
Application of Industrial Robots in the Automation of the Welding Process
}

\author{
IsakKarabegović* \\ Faculty of Technical Engineering, University of Bihać, Bosnia and Herzegovina
}

Submission: November 25, 2018; Published: December 11, 2018

*Corresponding author: IsakKarabegović, Faculty of Technical Engineering, University of Bihać, Bosnia and Herzegovina

\begin{abstract}
The application of industrial robots in the automation of production processes has been in the use since the 1960s. The automotive industry was the first to apply industrial robots and presents the forefront of using robots compared to other industries in the world. Industrial robots are used to perform tasks which are dangerous to human health. In the automotive industry, they are working in the process of welding vehicle bodywork and painting the car body, which provided the reason for the analysis of the application of robots in welding processes. Today we are in the fourth industrial revolution that the Germans named "Industry 4.0". The implementation of the fourth technological revolution depends on several new and innovative technological achievements, most of which are applied in robotic technology. Any automation of production processes, and thus the automation of the welding process, must include industrial robots. The paper presents the representation of industrial robots in the world, and top four countries: China, Japan, North America and Germany, where the automotive industry is most developed. Two welding processes that most commonly use industrial robots are Arc welding and Spot welding. An analysis of the application of industrial robots in these two the welding process was conducted for the period 2010-2016 for the continents of Asia, America and Europe, as well as in countries with highly developed automotive industry China, Japan, USA and Germany. The paper analyzes the application of industrial robots in Arc welding and Spot welding in these countries.
\end{abstract}

Keywords: Industrial robot; Welding process; Arc welding; Spot welding; Automation

\section{Introduction}

The process of automation in the industry began 60 years ago, with the use of first-generation industrial robots. Robots replaced people in performing jobs that are difficult and dangerous to their health. At first it was rigid and non-flexible automation, because if we needed the production of another product in the same production process it was necessary to reprogram every robot with its acceptors, change tools, etc., which required a production delay that lasted for a long time, causing additional costs in production. The presence of industrial robots is still the largest in the welding process of the automotive industry, but other branches of the industry are not lagging behind in increasing the use of industrial robots. Industrial robots are ideal for jobs that are considered difficult and unsuitable for people and jobs that are dangerous to their health, and these are precisely the tasks of the welding process. We constantly experience technological improvements in the flexibility, accuracy, security and simplification of the use of industrial robots [1-23]. The welding process itself is mostly used in the automotive industry for welding the vehicle body, where high precision is required. Industrial robots are used for Arc welding, Spot welding, Laser welding, Soldering and other types of welding. The paper analyzes the application of industrial robots in welding processes, both in the world and in the technologically developed countries where the automotive industry is developed.
Application of Industrial Robots in the World and in Countries of China, Japan, USA and Germany

In order to get the actual insight in the application of industrial robots in welding processes in the world and countries of China, Japan, USA and Germany, it is necessary to conduct an analysis of the application of industrial robots in all production processes of all industrial branches. For this analysis, we used the statistical data downloaded from The International Federation of Robotics (IFR), the UN Economic Commission for Europe (UNECE) and the Organization for Economic Co-operation and Development (OECD), as shown in the following figures [24-31,18].

Figure 1ab depicts the application of industrial robots in all production processes in the world on annual level. Based on Figure 1a we can conclude that the application is increasing every year and that with 60.011 units of robots in 2009, the application increased to 259.000 robot units in only seven years, which represents a four time increase in seven years. Similarly, the overall trend of industrial robot application is growing, as shown in Figure $1 \mathrm{~b}$, so that with around $1,020,731$ robot units in 2009 , in just seven years it increased to $1,828,024$ industrial robot units. The conclusion is that the application of industrial robots in the world is increasing, and the expectation is that this trend 


\section{Robotics \& Automation Engineering Journal}

will continue in the future, due to the fact that we are currently in the fourth industrial revolution whose implementation would be impossible without the use of industrial robots. In order to get the actual overview of the application of industrial robots in welding processes, we have conducted an analysis of the use of industrial robots in countries with the developed automotive industry, and the reason is that most industrial robots are applied in the automotive manufacturing processes. An analysis of the use of industrial robots in the following four countries was conducted: China, Japan, USA and Germany. The application is shown in Figure 2 [24-31].

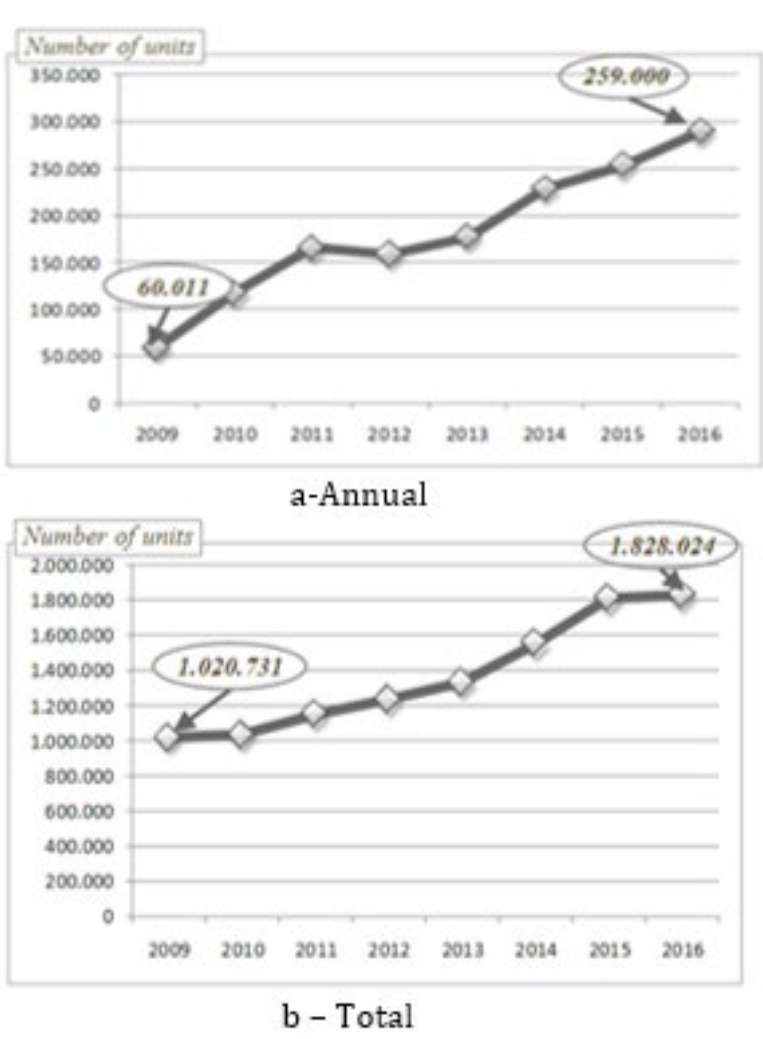

Figure 1ab: Application of industrial robots in the world for the period 2009-2016.

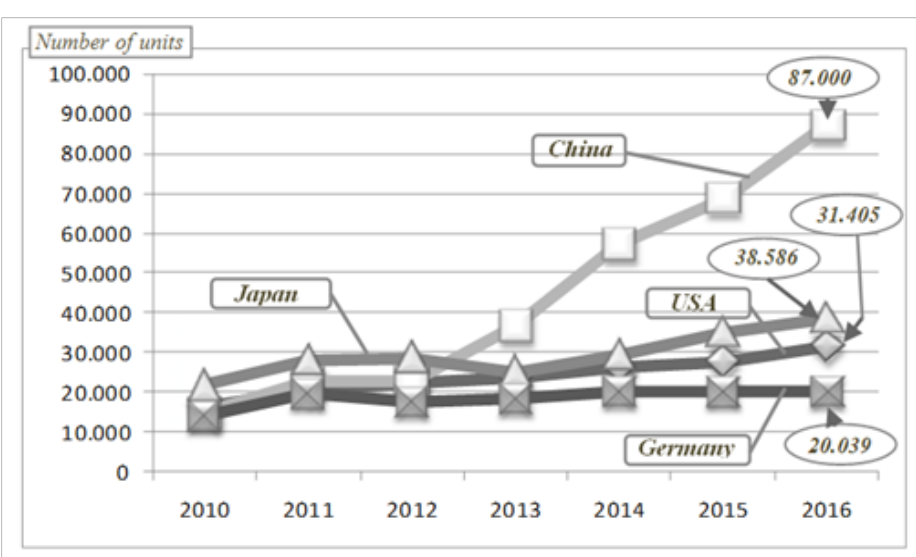

Figure 2: Application of industrial robots in countries of China, Japan, USA and Germany in the period 2010-2016.

The analysis of the application of industrial robots in countries such as China, Japan, USA and Germany, as shown in Figure 2, has shown that by 2012, the sequence of robot application was as follows: Japan in the first place, followed by China, USA and Germany. Since 2013 there has been a change in the first place. China has been increasing the use of industrial robots every year, so that in 2016 it reached the application of 87,000 robot units.
The second place is held Japan, followed by USA and Germany. In the last four years there has been a slight increase in the use of industrial robots in Japan, USA and Germany. The reason for the enormous increase of use of industrial robots lies in the implementation of the strategy entitled "Made in China 2025" by the Chinese Government, which aims to make China the most technologically developed country in the world. 


\section{Robotics \& Automation Engineering Journal}

Application of industrial robots in the welding production processes

The welding process itself creates gases that are dangerous to the health of workers who carry them out, so robots are installed in welding processes, thus protecting workers from tasks dangerous to their health (e.g. painting process). In the automotive industry, there are two welding methods, spot welding and arc welding, where industrial robots are mostly used. In order to obtain the real illustration of the automation of these jobs in the world, we need to conduct an analysis of the application of industrial robots in the welding processes. The application of industrial robots in welding processes is shown in Figure 3 and statistical data for the tendency of representation of industrial robots were taken from the literature [1,4,6,25-32].

As we can see in Figure 3, the tendency of industrial robot representation in welding processes in the world is growing in the period 2010-2016, disregarding slight deviations in 2012. In 2016 about 65.000 industrial robot units were used in the welding processes. Compared to the total use of industrial robots in the world in the same year, it can be seen that the representation in welding processes is $25 \%$, representing one quarter of used industrial robots in all processes worldwide. The first place by the presence of industrial robots in welding processes is held by Asia/Australia with growing tendency each year. In 2016 about 41.400 industrial robot units were used in Asia/Australia, representing $2 / 3$ of the total industrial robot representation in welding processes in the world. In the period from 2010 to 2016 the continent of Asia/Australia has increased the representation of robots in welding processes with total 23.000 robotic units, i.e. almost $100 \%$. Representation of industrial robots in welding processes is far behind on the continents of America and Europe, while the continent of Africa was eliminated in this analysis due to the fact that the representation is negligible in relation to other three continents. The representation of industrial robots in welding processes in the North America can be considered as constant each year, and in 2016 it was about 13.154 industrial robot units. On the continent of Europe, the illustration of industrial robot representation in welding processes is somewhat different, as the industrial robots' representation in 2010 and 2011 was higher than in the last five years. It can be said that the representation is constant from year to year (period 2012-2016), and in 2016 there were about 8.186 robot units. Therefore, we can conclude that the increasing tendency of industrial robot application in welding processes is to be expected, when compared to the overall tendency of industrial robot application on the continents, as shown in Figure 2, and the application of industrial robots by countries, as illustrated in Figure 3.

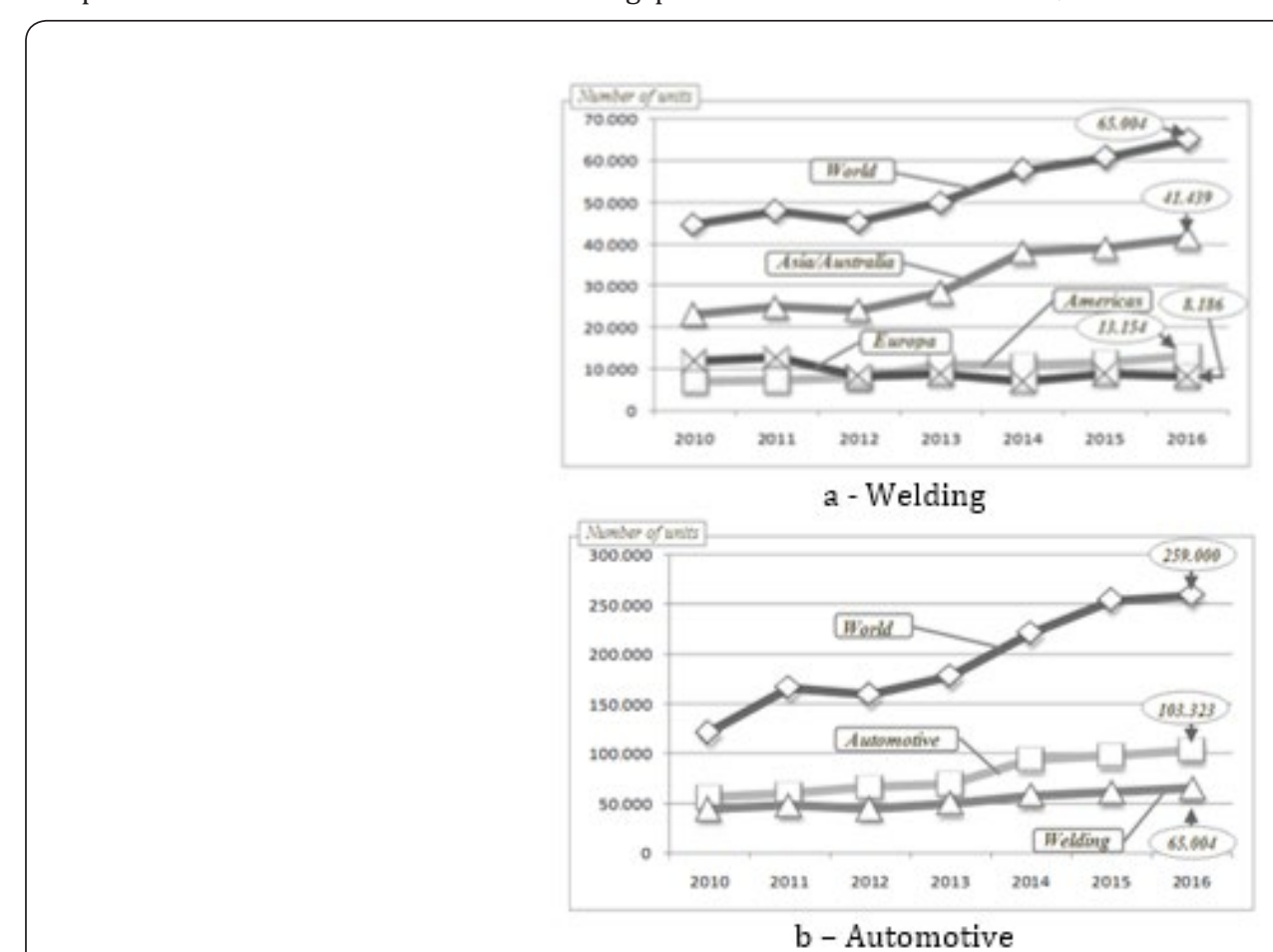

Figure 3: Application of industrial robots in the welding process worldwide and on the continents of Asia/Australia, Europe and North America and the application of robots in the automotive industry for the period 2010-2016.

The reason for this conclusion lies in the fact that China, which is located on the continent of Asia/Australia, is the country with the largest representation of industrial robots in the world, with a tendency of increasing application in the following years. Higher number of industrial robots is installed in the automotive industry where welding processes are represented [24,32,33,17-
23]. In order to obtain the actual illustration of the tendency of the representation of industrial robots in automotive industry and number of industrial robots installed in welding production processes, we have conducted an analysis of welding, Spot welding and Arc welding in the period 2010-2016, as shown in Figure 4 [7,24-31]. 


\section{Robotics \& Automation Engineering Journal}

Based on the tendency of application of industrial robots in welding and two welding processes, Arc welding process and Spot-welding process, in the period 2010-2016, as shown in Figure 4, we can conclude that Spot welding is in the first place in the world by the use of robots, in relation to the Arc welding process. In the last three years, the application of robots in Spot welding process is far greater than the application in Arc welding process. The reason for this difference lies in the fact that the production of vehicles in the world is increasing each year, where the process of Spot-welding process is mostly used in bodywork production. This is especially noticeable in China, which holds the first place in the vehicle production in the world, and in the application of industrial robots installed in the automotive industry. Approximately 34,056 robot units were applied in Spot welding in 2016, and about 24,415 units of robots in the Arc welding process. In order to obtain a ratio of representation of industrial robots in all welding processes in the world, we have analyzed the percentage of the use of industrial robots in 2016, as shown in Figure 5 [24].

As Figure 4 shows in 2016, around 65,000 units of industrial robots are used in all welding processes around the world. Based on the Figure 5 we see that the first place in the application of industrial robots is held by the Spot-welding process with about $52 \%$, which represents more than half of the industrial robots applied in all welding processes. Arc welding process is in the second place with about $39 \%$ and the last is the Laser welding process with about $1 \%$ of the applied robots. We conclude that the most industrial robots are installed in the Spot welding and Arc welding processes. An analysis of the representation of industrial robots in these two welding processes in the continents of America, Asia and Europe and Germany is shown in Figure 6 [5,24-31].

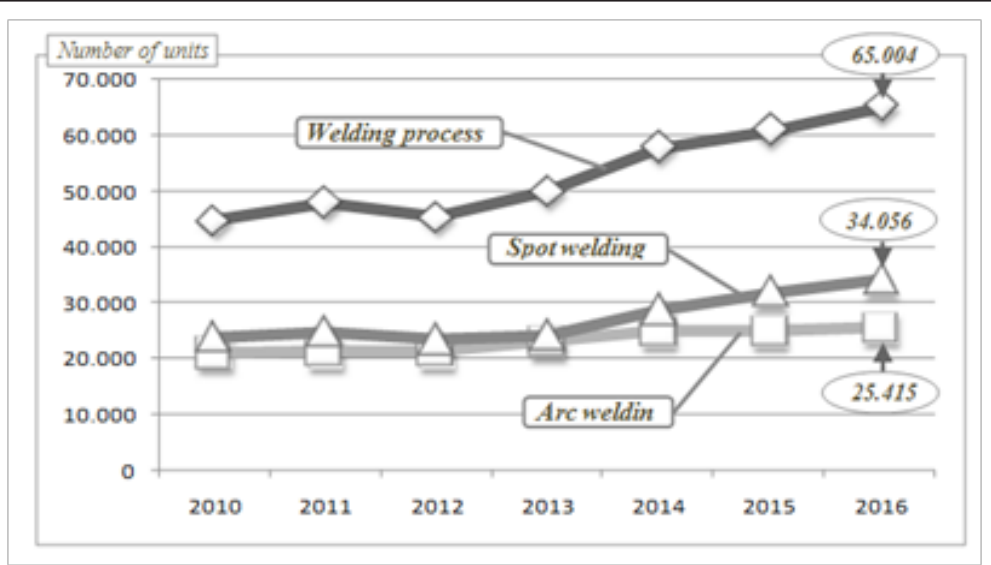

Figure 4: Application of industrial robots in two welding processes: Arc welding and Spot welding for the period 2010-2016 [7,16-23].

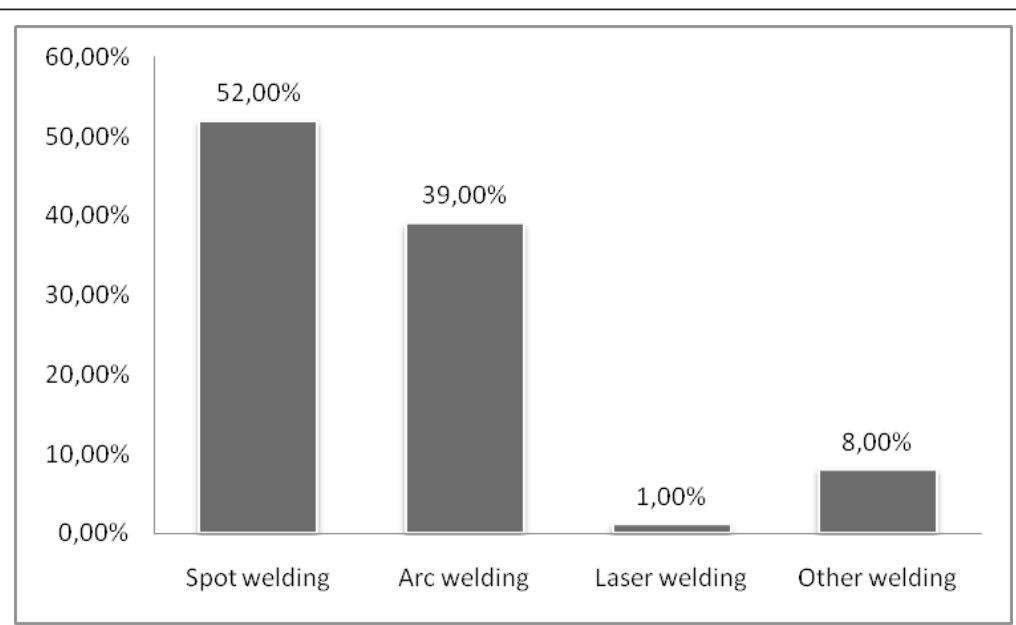

Figure 5: Application of industrial robots in all welding processes in the world for 2016, expressed in percentage [16].

The analysis of the representation of industrial robots in the Arc welding by continents (Figure 6a) indicates that the continent of Asia/Australia is the first place in the world with increasing tendency of representation. In 2016 there were about 16.805 industrial robot units applied in Asia/Australia, which is about four times more robot used than in Europe or North America in the same year. The second place is held by Europe with much smaller representation than Asia/Australia and a slight annual increasing tendency, which in 2016 amounted to 4.349 industrial robot units. The third place is held by North America with similar mild annual growth, which in 2016 reached 4.074 industrial robot units. The illustration of the representation of industrial robots in the process of Spot welding is different in comparison to Arc welding, as shown in Figure 6b). 


\section{Robotics \& Automation Engineering Journal}

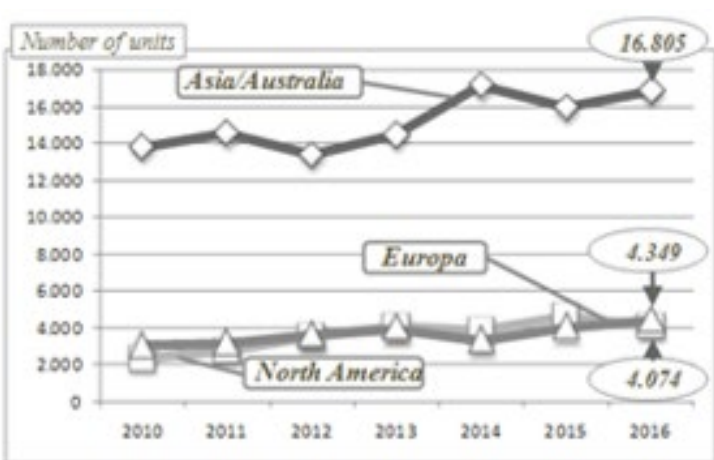

a- ARC welding

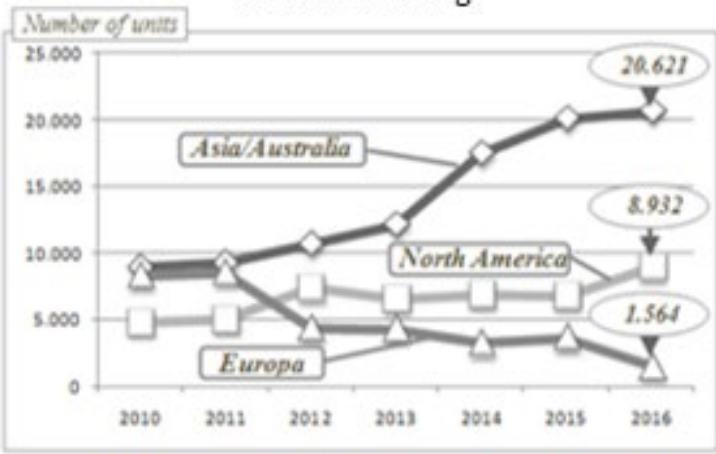

b-Spot welding

Figure 6: Application of industrial robots in Arc welding and Spot welding in countries: China, USA, Japan and Germany for the period 2010-2016.

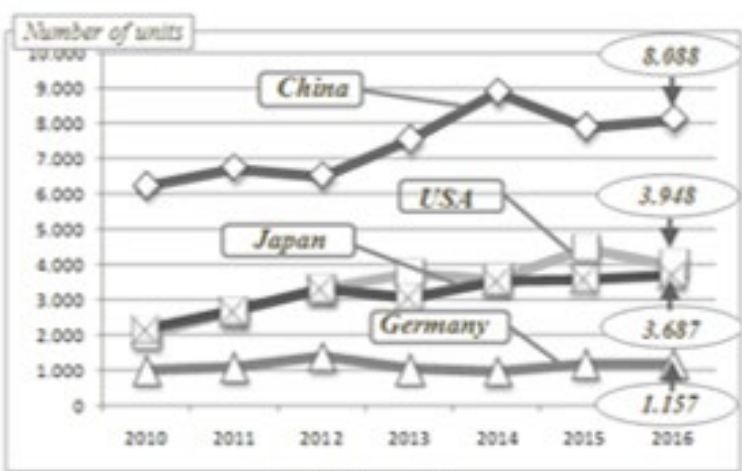

a-ARC welding

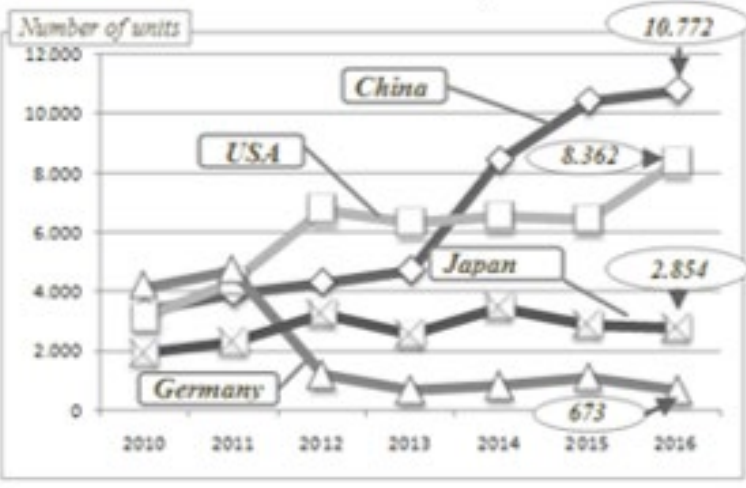

$\mathrm{b}$ - Spot welding

Figure 7: Application of industrial robots in Arc welding and Spot welding in countries of China, USA, Japan and Germany for the period 2010-2016. 


\section{Robotics \& Automation Engineering Journal}

We can see that the sudden tendency of annual increase of application of industrial robots in Asia/Australia in 2016 reached about 20.621 robot units, which is extremely high in relation to other countries when it comes to industrial robots and vehicle production. This is a consequence of Chinese technological development strategy named "Made in China 2025". The second place is held by North America with increasing representation of industrial robots in the Spot-welding process, that in 2016 amounted to about 8.932 industrial robot units, which is two times more than in Arc welding process. Europe is in the third place with the declining tendency of representation of industrial robots in the Spot-welding process, which in 2016 reached 1.564 industrial robot units. The reason for this reduced representation of industrial robots in Spot welding process are manifold, one of which being that the automotive companies are transferring their production processes outside of Europe. The representation of industrial robots in Arc welding and Spot-welding processes in the countries of China, USA, Japan and Germany is shown in Figure 7. [4,9,12-14,25-31].

Figure 7ab gives an overview of the application of industrial robots in Arc welding process and Spot-welding process in four countries with the developed automotive industry: China, USA, Japan and Germany. Based on Figure 7a, we can conclude that the first place in the use of robots in the Arc welding process is China, which in 2016 used about 8.088 robot units in this process. The second place is held by the USA, followed by Japan and Germany. This tendency is expected because China holds the first place in the world in the application of industrial robots. Unlike the Arc welding process, more robots are applied in the Spot-welding process as shown in Figure7b. Since 2014 China has been the world's first in the use of industrial robots in welding processes; Arc welding and Spot welding, which is logical since it is the world's first vehicle manufacturer (in 2016 it produced around 28 million vehicles [31]). The second place is held by the USA, followed by Japan and Germany, which in 2016 applied only about 673 robot units in the Spot-welding process. In 2016, Japan produced about 13 million vehicles, and Germany produced about 6 million vehicles in the same year. Such a trend in the application of industrial robots in the Spot-welding process in Japan and Germany is due to the fact that the two countries have shifted the production of vehicles to other countries in the world, so that industrial robots are applied in these countries (e.g. Czechoslovakia).

\section{Conclusion}

After the analysis of the application of industrial robots in the welding processes in the world, we can conclude that robots are most commonly used in two welding processes: Spot welding process and Arc welding process. These two processes are most used in the production of bodywork in the automotive industry, so that the leading countries in the application of industrial robots in welding processes are the ones where vehicles are mostly produced. The first place in the application of industrial robots in the welding process is held by Asia, and the reason is that Asia produces the most vehicles in the world. In regard to countries, the first place in the application of industrial robots in welding processes is held by China. The first reason is that China is the world's first vehicle producer, and the second being that China is pursuing a government strategy called "Made in China 2025", which aims to position China as the first technologically developed country in the world by 2025. In relation to the welding process, the first place in the application of industrial robots in the world is held by the Spot-welding process, because this process is mostly used in the production of vehicle bodywork. It is expected that the use of industrial robots will increase in welding processes in the coming years.

\section{References}

1. Karabegović I, Riaz M (2018) Automation of the Welding Process by Use of Industrial Robots. New Technologies, Development and Application,NT 2018,LNNS 42, Springer International Publishing, Cham, Switzerland, pp. 3-17.

2. Doleček V, Karabegović I (2002) Robotika. Tehničkifakultet Bihać, Bihać.

3. Doleček V, Karabegović I (2008) Roboti u industriji. Tehničkifakultet Bihać, Bihać.

4. Karabegović I (2016) Role of Industrial Robots in the Development of Automotive Industry in China. International Journal of Engineering Works 3(12): 92-97.

5. Karabegović I, Husak E (2014) Significance of industrial robots in development of automobile industry in Europe and the World. Journal Mobility and Vehicle, University of Kragujevac, Faculty of Engineering, Kragujevac, Serbia 40(1): 7-16.

6. Karabegović I (2017) The Role of Industrial and Service Robots in Fourth Industrial Revolution with Focus on China. Journal of Engineering and Architecture 5(2): 110-117.

7. Kalpakjian S, Schmid S (2008) Manufacturing Processes for Engineering Materials ( $5^{\text {th }}$ edn), Amazon Book Review, USA.

8. Sulavik C, Portnoy M, Waller T (2014) How a new generation of robots is transforming manufacturing, PwC Global, New York, USA.

9. De Luca A (2016) Industrijal Robotics. Sapienze University of Roma, Roma, Italia.

10. Craig J (2005) Introduction to Robotics Mechanics and Control. (3 $3^{\text {rd }}$ edn), Pearson Education Ltd., London, UK.

11. Wloka D (1992) Robotersysteme 1. Springer Vorlag, Berlin, Deutschland.

12. Davis Pluess J (2015) Good Jobs in the Age of Automation. BSR-The Business of a Better World, New York, USA, 2015: 1-28.

13. Gemma J, Verl A, Litzenberger G (2016) IFR Press Conference, International Federation of Robotics. Frankfurt, Germany.

14. Bunse B, Kagermann H, Wahlster W (2016) Industrie 4.0-Smart Manufacturing for the Future. Germany Trade and Invest, Berlin, Germany.

15. World Robotics (2011) IFR Statistical Department, hosted by VDMA Robotics+ Automation, Germany.

16. Makowieckaja O (2015) Industrial Robots on the Market of Means of Production Automation. Biuletyn Instytute Spawalnictwa, No. 2. Gliwice, Czechoslovak, pp. 22-27.

17. Holdren J, Smith M (2016) Preparing for the future of artificial intelligence. National Science and Technology Council Committee on Technology, Washington, USA, pp. 29-32. 


\section{Robotics \& Automation Engineering Journal}

18. Wright R (2015) Robots and Industrialization in Developing Countries UNCTAD/PRESS/PB/2016/6, No. 50, United Nations Conference on Trade and Development UNCATD, Geneva, Switzerland, pp. 1-4.

19. Paper W (2015) Robots Fuel the Next Wave of US Productivity and Job Growth. Association for Advancing Automation, Michigen, USA, pp. 1119.

20. Robotics 2020 (2013) Strategic Research Agenda for Robotics in Europe. euRoboticsaisbl, Draft 0v42 11/10/ euRobotics, New York, USA, pp.25-43.

21. Schwab K (2016) The Fouth Industrial Revolution. World Economic Forum, Geneva, Switzerland, pp. 19-27.

22. Yang G, Bellingham J, Dupont P, Fischer P, Floridi L, et al. (2018) The grand challenges of Science Robotics. Science Robotics 3(14): 1-15.

23. Struijk B (2012) Robot Production Volume Data Trends and Analysis. Debreceni Muszaki Kozlemenyek, Debrecen, Hungary, pp.1-10.

24. World Robotics 2017 (2017) IFR Statistical Department. hosted by VDMA Robotics+Automation, Germany.

25. World Robotics 2016 (2016) IFR Statistical Department. hosted by VDMA Robotics+Automation, Germany.

26. World Robotics 2015 (2015) IFR Statistical Department. hosted by VDMA Robotics+Automation, Germany.

This work is licensed under Creative Commons Attribution 4.0 License

DOI: 10.19080/RAEJ.2018.04.555628
27. World Robotics 2014 (2014) IFR Statistical Department. hosted by VDMA Robotics+ Automation, Germany.

28. World Robotics 2013 (2013) IFR Statistical Department. hosted by VDMA Robotics+ Automation, Germany.

29. World Robotics 2012 (2012) IFR Statistical Department. hosted by VDMA Robotics+ Automation, Germany.

30. Karabegović I, Husak E (2016) China as a leading country in the world in automation of automotive industry manufacturing processes. Journal Mobility and Vehicle 42(3): 15-22.

31. Dolphin T (2015) Technology, globalisation and the future of work in Europe. Institute for Public Policy Research, London, UK.

32. Mannan B, Khurana S (2012) Enablers and Barriers for Introduction of Robotics as an AMT in the Indian Industries (Case of SME's). International Journal of Computer Applications, New York, USA pp.1924.

33. Ray J, Atha K, Francis E, Dependahl C, Mulvenon J, et al. (2016) China's Industrial and Military Robotics Development, Research Report Prepared on Behalf of the U.S.-China Economic and Security Review, Vienna, Austria, pp. 78-84.

\section{Your next submission with Juniper Publishers} will reach you the below assets

- Quality Editorial service

- Swift Peer Review

- Reprints availability

- E-prints Service

- Manuscript Podcast for convenient understanding

- Global attainment for your research

- Manuscript accessibility in different formats

( Pdf, E-pub, Full Text, Audio)

- Unceasing customer service

Track the below URL for one-step submission https://juniperpublishers.com/online-submission.php 